Мартинів Ольга Олексіївна викладач кафедри культурології та мистецької освіти, Дрогобицький державний педагогічний університет ім. Івана Франка, вул. I. Франка, 24, м. Дрогобич, 82100, e-mail: martyniv07@gmail.com, https://orcid.org/0000-0001-7381-8506

Мартинів Любомир Ігорович кандидат мистецтвознавства, доцент, провідний концертмейстер кафедри культурології та мистецької освіти, Дрогобицький державний педагогічний університет ім. Івана Франка, вул. I. Франка, 24, м. Дрогобич, 82100, e-mail: liubomyrmartyniv26@gmail.com, https://orcid.org/0000-0001-7826-3968

\title{
ІННОВАЦІЙНІ ОСВІТНІ ТЕХНОЛОГІЇ У ПІДГОТОВЦІ ХОРЕОГРАФІВ
}

Анотація. У статті розглянуто важливість питання застосування інноваційних освітніх технологій у процесі підготовки майбутніх хореографів. Розкрито фундаментальні основи хореографії в освітньому дискурсі. Проведено аналіз спеціалізованої літератури та останніх публікацій 3 цього питання. Визначено властивості технологій і педагогічних інновацій, що застосовуються в хореографічній освіті. Наведено приклади застосування інноваційних освітніх технологій. У якості методів дослідження обрано аналітичний підхід, порівняльний аналіз літератури, мистецтво хореографії та педагогічні інновації, наукове узагальнення результатів кабінетного дослідження. Висвітлено поняття педагогічної інновації, окреслено межі розуміння цього терміну. У якості основного методу впровадження інноваційних підходів у хореографічній освіті запропоновано всебічне застосування можливостей мережі Інтернет. Встановлено, що за допомогою відеохостингів можна долучитися до світової культурної спадщини та проводити дослідження хореографічних постановок світової класики. Мережа Інтернет зберігає у собі невичерпний прошарок освітнього матеріалу. Разом з тим платформи сучасних меседжерів можуть бути використані у якості площадок для проведення онлайн майстер-класів відомими хореографами. Відтак інноваційні моделі хореографічної освіти сьогодні повинні будуватися з урахуванням цифрової трансформації царини освіти. Визначено, що інновації полегшують викладачеві здійснення теоретичної та контрольної частин навчання. Коли справа доходить до практики, ніякі технології не можуть замінити досвід наставника, його рекомендації, що дозволяють вчасно помітити помилки і упущення при постановці хореографічного твору.

Ключові слова: інновації, заклад вищої освіти, практична підготовка, хореографічно-педагогічна освіта. 
Martyniv Olha Oleksiivna Lecturer of the Department of Cultural Studies and Art Education of the Drogobych State Pedagogical University named after. I. Franko, Ivan Franko St., 24, Drohobych, 82100, e-mail: martyniv07@gmail.com, https://orcid.org/0000-0001-7381-8506

Martyniv Liubomyr Ihorovych Candidate of Art Criticism (PhD), leading concertmaster of the Department of Cultural Studies and Art Education of the Drogobych State Pedagogical University named after. I. Franko, Ivan Franko St., 24, Drohobych, 82100, e-mail: liubomyrmartyniv26@gmail.com, https://orcid.org/00000001-7826-3968

\section{INNOVATIVE EDUCATIONAL TECHNOLOGIES IN THE PREPARATION OF CHOREOGRAPHERS}

Abstract. The article considers the importance of the application of innovative educational technologies in the process of training future choreographers. The fundamental foundations of choreography in educational discourse are revealed. An analysis of specialized literature and recent publications on this issue. The properties of technologies and pedagogical innovations used in choreographic education are determined. Examples of application of innovative educational technologies are given. Analytical approach, comparative analysis of literature, art of choreography and pedagogical innovations, scientific generalization of results of office research are chosen as research methods. The concept of pedagogical innovation is covered, the limits of understanding this term are outlined. As a basic method of introducing innovative approaches in choreographic education, a comprehensive application of the Internet is proposed. It is established that with the help of video hosting you can join the world cultural heritage and conduct research on choreographic productions of world classics. The Internet stores an inexhaustible layer of educational material. However, the platforms of modern messengers can be used as platforms for online workshops by well-known choreographers. Therefore, innovative models of choreographic education today must be built taking into account the digital transformation of the field of education. It is determined that innovations facilitate the teacher's implementation of theoretical and control parts of learning. When it comes to practice, no technology can replace the experience of the mentor, his recommendations, which allow you to spot mistakes and omissions in the production of a choreographic work.

Keywords: innovations, institution of higher education, practical training, choreographic and pedagogical education.

Постановка проблеми. Актуальність обраної теми зумовлена необхідністю відповідати на сучасні виклики сьогодення, а саме спонукати студентахореографа до постійного, неперервного особистого розвитку. Сучасна хореографічна освіта орієнтована на всебічний розвиток особистості студента, його пізнавальних і творчих здібностей, що передбачає його творчий розвиток в 
цілісному навчально-виховному процесі. Творча діяльність - головна умова розвитку особистості. Мистецтво хореографії утворює цілий ряд різновидів танців в ході свого розвитку протягом багатьох тисячоліть. Це призвело до того, що кожен може вибрати для себе той стиль танцю, який йому властивий $\mathrm{i}$ безпосередньо приносить велике задоволення та виражає внутрішній світ. Це допомагає розвиватися, набиратися досвіду, напрацьовувати певні навички, підвищувати тим самим свою майстерність в окремому, обраному для себе напрямку.

Аналіз останніх досліджень і публікацій. Над питанням про виховання особистості майбутнього хореографа працювали багато психологів і педагогів. Методологічною основою дослідження є психолого-педагогічні, культурологічні положення: у царині психолого-педагогічних досліджень про значення навчання, його зміст і методи організації навчально-виховного процесу з урахуванням психофізіологічних можливостей дітей: Ю.К.Бабанського, J. С. Виготського, А. Н. Леонтьєва, І. Я. Лернера, С. Л. Рубінштейна, М. Н. Скаткіна, В. А. Сухомлинського та інших; за методикою виховання, спрямованого на навчання різноманітним видам художньо-творчій діяльності: А. В. Антонової, О. А. Апраксиної, Л. Р. Арчажникової, Н. А. Ветлугиної, В. О. Краєвського,

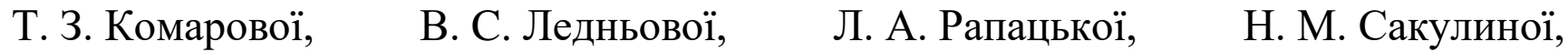
Е. А. Флериної та інших; 3 питань навчання хореографії, змісту і значення фізичного виховання у формуванні особистості: І. А. Бадіної, Н. П. Базарової, А. Я. Ваганової, П. Ф. Лесгафта, Р. А. Ільїної, В. С. Костровицкої, М. В. Левіна, В. П. Мейя, В. А. Моїсеєвої, 3. С. Миронової, Е. Р. Попової, Т. А. Устинової та інших.

У зв'язку з цим стає актуальним питання доступу до необхідних для ознайомлення та подальшого вивчення матеріалів (музичні партитури, лібрето, аудіо та відеозаписи балетів, мініатюр та іншого). На допомогу сучасному студенту приходять інноваційні інтернет-технології: великі сервіси, що містять аудіо та відео контент (Youtube, Vimeo), офіційні сайти відомих на весь світ театрів опери та балету, сайти з електронними книгами і статтями 3 хореографії. Таким чином, студенти можуть ознайомитися в режимі наживо 3 безліччю хореографічних творів. В аспекті забезпеченості навчально-методичним матеріалом у сфері хореографічного навчання сьогодні не виникає особливо гострих проблем. Однак, перш ніж продовжити вивчення взаємодії технологій i освітнього процесу, слід прояснити теоретичні аспекти категорій «танець», «художній образ» і «педагогічна інновація».

Мета статті $\epsilon$ висвітлення особливостей застосування інноваційних педагогічних методів у системі хореографічної освіти з використанням сучасних інформаційних технологій.

Методи дослідження. В якості основних методів дослідження у статті застосовано аналітичний підхід, порівняльний аналіз літератури про мистецтво хореографії та педагогічні інновації, наукове узагальнення результатів кабінетного дослідження науково-методичної літератури, критичний аналіз 
сучасних умов і можливостей педагогічного процесу в області хореографії. Порівняльний аналіз наукової літератури, присвяченої хореографічній діяльності та педагогічним інноваціям, а також ії узагальнення та критичне осмислення дозволили виділити характерні особливості інноваційної підготовки сучасного хореографа та педагогічних умов на сучасному етапі розвитку як педагогічної науки, так і хореографічного мистецтва. Тому вирішено приділити основну увагу питанням взаємодії технологій і процесу навчання в танцювальному мистецтві як інноваційному синтезу сучасних технологій та досвіду викладацької майстерності [1].

Виклад основного матеріалу. Танець - це особливий вид мистецтва, де в якості інструментів вираження образів, почуттів і емоцій виступає людське тіло у музичному супроводі. Танець сприяє фізичній підготовці, а також створює умови для естетичного і психологічного розвитку, що є дуже важливим фактором для формування здорового покоління.

За словами сучасного дослідника Л. М. Андрощук, «сьогодні термін «інновація» носить міждисциплінарний характер і використовується в термінологічному апараті різних галузевих наук, в тому числі і педагогіки» [2]. Тому існує різноголосся в питанні визначення інновації як поняття - кожна область знань пропонує свою дефініцію 3 урахуванням специфіки сфери застосування терміну. Нам же, щоб уникнути абстрактності, слід звернутися до запропонованих конкретних визначень 3 галузі освіти. «Під педагогічними інноваціями, - згідно досліджень О. Бикової, - маються на увазі нововведення в педагогічній системі, що поліпшують перебіг і результати навчально-виховного процесу» [3]. Визначення не викликає питань, воно може послужити основою для подальших розробок і інтерпретацій.

Проте існують дослідження, які також можуть допомогти нам розкрити особливості поняття «педагогічна інновація» з інших позицій. У Казахстані деякі аспекти застосування інноваційних технологій в музичній педагогіці розглядає Ю.В. Голенкова. Її дослідження представляє для автора особливий інтерес, оскільки іiі робота заснована на вивченні інновацій в суміжних областях мистецтва і педагогіки.

Так Ю. В. Голенкова розглядає педагогічні інновації в динаміці і вважає, що це - «процес вдосконалення педагогічних технологій, набору методів навчання, підходів та інструментів» [4]. На думку автора, ця дефініція може бути застосована i до хореографії. Далі розглянемо педагогічні інновації в танцювальному мистецтві. Як згадувалося вище, сучасні технології та інтернет відкривають доступ до колосального обсягу інформації для навчання балетмейстерів. У зв'язку з цим окремого розгляду заслуговують засоби перегляду різного роду матеріалів (аудіо та відеозаписів, електронних статей, книг та іншого): комп'ютери, ноутбуки, планшети, смартфони.

Художній образ є особливою формою відображення і осмислення життя. Мистецтво все без винятку пропускає через естетичну призму, облагороджуючи естетичним переживанням. Чи не основним у роботі хореографа $є$ життєві 
спостереження. Тільки життя у всьому його різноманітті може стати матеріалом для будь-якого художника.

Наша свідомість, наше відчуття $є$ лише образ нашого світу. Від живого споглядання до абстрактного мислення i від нього до практики - такий діалектичний шлях пізнання, руху до істини, пізнання неупередженої реальності. Хореографічний образ відображає конкретний характер людини, тварини, птиці та інших істот, що виявляється у відношенні зображуваного до навколишньої дійсності [5].

Характер героя розкривається на сцені в лінії його поведінки, в його діях i вчинках засобами хореографічного мистецтва. Кожен хореографічний твір будується за законами драматургії. Хореографічний образ також не може створюватися без урахування цих законів. У сценічному образі повинна бути i своя експозиція, і зав'язка, і кульмінація, і розв'язка. Інноваційна хореографічна освіта повинна бути спрямована на розвиток самого відчуття гармонії руху в усій своїй різноманітності [6].

Сьогодні хореографічна творчість надзвичайно різнобарвна в плані балетмейстерських стилів і напрямків, також накопичено багатий досвід в теорії і практиці створення хореографічних творів. Кожен автор, творець танцювального номера повинен мати чіткі уявлення про виразні засоби i можливості хореографічного мистецтва, знати закони драматургії, принципи їх сценічного втілення. Всі ці питання роблять проблему звернення хореографічної освіти до інноваційних технологій актуальною і показують перспективи подальшої роботи з даної теми [7].

Так як мистецтво хореографії тісно пов'язане з музикою, хореографічну інноваційну освіту слід розглядати в тісній взаємодії з музичним твором [8]. Будь-який художник-хореограф, в залежності від своїх особливостей, рівня культури, індивідуальності мислення, застосовує i свої особливі прийоми. Наприклад, створюючи твір на історичну тему, будь-який хореограф спочатку вивчить особливості епохи, в яку відбувається подія, портрети історичних діячів, літературу, живопис - все, що зможе дати поштовх фантазії [3]. Але який буде результат, який образ складеться в його голові, залежить від його особистості.

Проводячи аналіз всього комплексу отриманих знань, вражень, хореограф виробляє своє судження, свій погляд. Уміння зробити головний, найважливіший вибір має величезне значення для кінцевого результату роботи - хореографічного твору. При створенні образу величезну роль відіграє знання хореографом психології героя. Воно дає можливість не тільки розуміти характери людей, що зустрічаються в житті, а й правильно вибудовувати - спочатку в своїй уяві, а потім і на сцені лінію поведінки героїв хореографічного твору [9].

Танець входить до складу різних видів мистецтва, як класичних, так i сучасних. У першому випадку ми маємо на увазі балет, а на сучасному етапі хореографія використовується в нетрадиційних формах авангардного мистецтва. У століття постмодерну мистецтво насамперед відмовилося від реалістичного розуміння світу, наслідком чого став пошук нових засобів вираження. У суворій 
відповідності з цим синтез на глобальному рівні існування культури можна розуміти як особливу систему виразності для хореографії, укладену в тілесному аспекті художнього образу. Саме по собі звернення до різнорідних форм пластики, в яких укладені неосвоєні можливості людського тіла, що виходять за межі класичних форм танцю, дає цікаві результати. Прикладом цього може служити хореографія О.М. Пархоменко, орієнтована на створення універсального танцю, в якому закладено екзистенціальний сенс [10]. Вбираючи в себе всі історичні та етнічні тенденції зростання мистецтва, балетмейстер синтезує техніку всіх видів.

Грамотна організація навчання танцювального мистецтва має велике значення. «Основне завдання організаційної частини уроку - налаштувати студентів на майбутню діяльність, допомогти їм перейти від побутового настрою до художнього» [1].

Інноваційними методами викладання хореографії $\epsilon$ педагогічні методи 3 використанням нововведень, спрямовані на отримання більш високих результатів від освітньої діяльності [4]. Цілями інноваційних педагогічних методів у викладанні хореографії є:

- розширення діапазону одержуваної інформації за рахунок впровадження в навчальний процес більш широкого спектру навчального матеріалу;

- формування стійких навичок і їх успішне застосування на практиці;

- зростання мотивації за рахунок впровадження в процес навчання хореографічному мистецтву навчального матеріалу, відмінного від традиційних, більш цікавого i насиченого, заснованого на тісному зв'язку теорії 3 практикою [10].

Навички педагогічно-хореографічної роботи студенти отримують при вивченні таких дисциплін як «Теорія i методика навчання класичного/народного/сучасного танцю», «Мистецтво балетмейстера». Незважаючи на введену педагогічну складову в спеціальність, освітній процес побудований на традиційній моделі навчання, що полягає у формуванні виконавських якостей. На практиці зустрічається проблема невизначеності методик викладання хореографічних дисциплін і відсутності цілісності в процесі підготовки студентів навчальних закладів культури і мистецтва.

Педагогіка хореографії в цій гілці освіти орієнтована, в першу чергу, на застосування власне хореографічних знань, умінь i навичок. Педагоги бачать своїм основним завданням розкриття творчої індивідуальності керівника хореографічного колективу i не завжди приділяють належну увагу науковому обгрунтуванню методик подальшої передачі знань і умінь. Художньо-творча діяльність в стінах цих навчальних закладів пов'язана більшою мірою зі створенням і виконанням хореографічних творів [13].

Для вирішення проблеми всебічного використання інформаційних інноваційних засобів у підготовці майбутніх хореографів широкої популярності набувають дистанційні форми навчання у хореографічній освіті. Соціальні мережі та меседжери сьогодні стали найпопулярнішим засобом комунікацій i 
споживання інформації. Інтернет дозволяє викладачеві в будь-який вільний час фіксувати пропуски і успішність учнів в електронних журналах, а студентам регулярно стежити за оцінками. Мобільні додатки забезпечують доступ до безкоштовних відеоресурсів (Youtube, Vimeo), відеодзвінків і чатів (Skype, WhatsApp, Viber, Telegram, Facebook). Так як «важлива особливість інновацій в системі професійної освіти полягає в тому, що суб'єктами інноваційного процесу $\epsilon$ учень і педагог» [10], особливо серед перерахованих додатків виділяється WhatsApp, що забезпечує постійну комунікацію суб'єктів. На прикладі цього додатка можна легко пояснити процес впровадження нововведень в освітню сферу.

При цьому, в першу чергу, були встановлені основні етичні рамки користування чатом - це заборони на прохання відлучитися від занять, прохання дати дозвіл на запізнення, обмін повідомленнями і записами в пізній час доби та інші найбільш ймовірні ситуації. До позитивних аспектів користування чатом для студентів можна віднести:

- регулярний доступ (в ранковий, денний і вечірній час) до спілкування 3 викладачем і групою по пройденим або майбутнім темам уроків;

- можливість задавати питання і просити рекомендації при виконанні самостійної роботи;

- обмін корисними аудіо і відео файлами, статтями і книгами в електронних форматах, посиланнями на сайти [15].

Таким чином, інноваційні підходи до навчання із застосуванням сучасних технологій дозволяють забезпечити безперервний процес отримання знань практично в будь-який зручний для студентів час.

Висновки. У статті розкрито властивості технологій i педагогічних інновацій, що застосовуються в хореографічній освіті. Щоб підкреслити користь сучасних засобів і підходів до навчання, наведені імена найбільш значущих і відомих вчених у царині хореографії. Це дає можливість представити колосальний обсяг знань, які необхідні сучасним хореографам. В оволодінні попереднім світовим досвідом у мистецтві хореографа сьогодні допомагають інноваційні технології та засоби телекомунікації. Вони «дозволяють реалізувати практично весь цикл навчання від лекцій до контрольних заходів. Застосування обчислювальної техніки в освіті дозволяє підвищити якість навчання, створити нові засоби виховного впливу, засоби ефективної взаємодії викладача і учня, прискорити передачу знань».

Таким чином, інновації полегшують викладачеві здійснення теоретичної та контрольної частин навчання. Коли справа доходить до практики, ніякі технології не можуть замінити досвід наставника, його рекомендації, що дозволяють вчасно помітити помилки і упущення при постановці хореографічного твору. Крім того не слід забувати, що широке коло знань ще не гарантує успіху у майбутньому. Адже хореограф «повинен бути мислителем, психологом і педагогом», який шукає і відкриває власну унікальну мову пластики і танцю, а не повторює досліди минулого. 


\section{Лimepamypa:}

1. Андрощук Л. М. Бар'єри розвитку хореографічно-педагогічної освіти як інноваційного явища. Емпіричні дослідження для реформування освіти в Україні: зб. матеріалів I Міжнар. наук. конф. Української асоціації дослідників освіти (Київ, 11 лют. 2017 р.). Київ; Дрогобич: ТзОВ «ТрекЛТД», 2017. С. 1114.

2. Андрощук Л. М. Роль науково-методичних видань у підготовці майбутніх учителів в системі хореографічно-педагогічної освіти. Наукові записки Кіровоградського державного педагогічного університету імені Володимира Винниченка. Серія: Педагогічні науки. 2017. Вип. 152. С. 97-102.

3. Бикова О. Педагогічні умови розвитку індивідуальних творчих здібностей майбутніх учителів хореографії у процесі фахової підготовки. Молодь і ринок. 2016. № 8. С. 146-150.

4. Голенкова Ю. В., Пальчук Н. І. Вплив засобів ритміки і хореографії на фізичну підготовленість дітей молодшого шкільного віку. Теорія та методика фізичного виховання. 2014. №3. C. 39 43. DOI: http://dx.doi.org/10.17309/ tmfv.2014.3.1106.

5. Каминская Е. Ю. Инновационные технологии как явление и их особенности при обучении хореографии. Образование и воспитание. 2018. № 2. С. 54-58.

6. Куценко С. В. Педагогічна майстерність майбутнього вчителя хореографії як гарант ефективності формування його творчого потенціалу. Актуальні питання мистецької освіти та виховання. 2015. Вип. 1-2. С. 113-121.

7. Мартиненко О. В. Вектори успішної підготовки фахівців хореографічного профілю. Розвиток творчого потенціалу майбутніх фахівців мистецьких дисциплін як фактор їх професійної самореалізації: колективна монографія / Мартиненко О. В. та ін.; за ред. А. І. Омельченко. Мелітополь: Видавничий будинок Мелітопольської міської друкарні, 2019. С. 164-189.

8. Ніколаї Г. Ю. Предмет і теоретико-методологічні основи хореографічнопедагогічної компаративістики. Сучасні стратегії розвитку хореографічної освіти : матеріали II Всеукр. наук.-практ. конф. (Умань, 16-17 трав. 2015 р.). Умань: ФОП Жовтий О. О., 2015. С. 71-74.

9. Пархоменко О. М. До проблеми балетмейстерської підготовки майбутніх 241 учителів хореографії у системі вищої мистецької освіти. Наукові записки Ніжинського державного університету імені Миколи Гоголя. Серія: Психолого-педагогічні науки. 2018. № 1. С. 33-38.

10. Пархоменко О. М. Основні аспекти моделювання хореографічного твору в процесі балетмейстерської діяльності майбутнього вчителя хореографії. Теорія і методика мистецької освіти. 2019. Вип. 3. С. 118-124.

11. Радченко О.Л. Специфіка професійної підготовки хореографапедагога, керівника хореографічного колективу в мистецьких навчальних закладах I-II рівня акредитації. URL : http://www.kukim.org/articles/specifikaprofesiynoyi-pidgotovki-horeografa-pedagoga-kerivnikahoreografichnogokolektivu (дата звернення: 30.09.2021).

12. Реброва О.Є. Конструювання організаційно-методичної системи як стратегія фахової підготовки майбутніх учителів музики і хореографії. Наукові записки Центральноукраїнського державного педагогічного університету імені Володимира Винниченка. Серія: Педагогічні науки. 2017. Вип. 152. С. 41-46.

13. Сало Л. В. Особливості підготовки хореографів у Каліфорнійському державному університеті. Міжкультурна взаємодія та комунікація: традиції, сучасність, перспективи : матеріали Всеукр. наук.-практ. конф. (Канів, 1415 трав. 2019 р.). Канів, 2019. С. 80-82.

14. Стандарт вищої освіти України. Перший (бакалаврський) рівень. Галузь знань: 02 Культура і мистецтво. Спеціальність: 024. Хореографія. Київ: Міністерство освіти і науки України, 2020. 19 с.

15. Тараненко Ю. П., Коваль Л. В. Компетентнісний підхід у процесі професійної підготовки майбутніх учителів хореографії. Наука і молодь в XXI сторіччі: зб. тез доповідей II Міжнар. молодіжної наук.-практ. Інтернетконф. (Полтава, 1-2 груд. 2016 р.): в 3 ч. Полтава: ПУЕТ, 2016. Ч. 2. C. 197-199. 


\section{References:}

1 Androshchuk, L. M. (2017). Bariery rozvytku khoreohrafichno-pedahohichnoi osvity yak innovatsiinoho yavyshcha [Barriers to the development of choreographic and pedagogical education as an innovative phenomenon]. Empirychni doslidzhennia dlia reformuvannia osvity v Ukraini: $\mathrm{zb}$. materialiv I Mizhnar. nauk. konf. Ukrainskoi asotsiatsii doslidnykiv osvity (Kyiv, 11 liut. 2017 r.). Kyiv; Drohobych : TzOV «TrekLTD», 11-14 [in Ukrainian].

2. Androshchuk, L. M. (2017). Rol naukovo-metodychnykh vydan u pidhotovtsi maibutnikh uchyteliv v systemi khoreohrafichno-pedahohichnoi osvity [The role of scientific and methodological publications in the training of future teachers in the system of choreographic and pedagogical education]. Naukovi zapysky Kirovohradskoho derzhavnoho pedahohichnoho universytetu imeni Volodymyra Vynnychenka. Seriia : Pedahohichni nauky - Scientific notes of Kirovohrad State Pedagogical University named after Volodymyr Vynnychenko. Series: Pedagogical sciences, 152, 97-102 [in Ukrainian].

3. Bykova, O. (2016). Pedahohichni umovy rozvytku indyvidualnykh tvorchykh zdibnostei maibutnikh uchyteliv khoreohrafii u protsesi fakhovoi pidhotovky [Pedagogical conditions for the development of individual creative abilities of future teachers of choreography in the process of professional training]. Molod i rynok - Youth and the market, 8, 146-150 [in Ukrainian].

4. Holenkova, Yu. V. \& Palchuk, N. I. (2014). Vplyv zasobiv rytmiky i khoreohrafii na fizychnu pidhotovlenist ditei molodshoho shkilnoho viku [Influence of means of rhythmics and choreography on physical fitness of children of primary school age]. Teoriia ta metodyka fizychnoho vykhovannia - Theory and methods of physical education, 3, 39-43. DOI: http://dx.doi.org/10.17309/ tmfv.2014.3.1106 [in Ukrainian].

5. Kamynskaia, E. Yu. (2018). Ynnovatsyonnыe tekhnolohyy kak yavlenye y ykh osobennosty pry obuchenyy khoreohrafyy [Innovative technologies as a phenomenon and their features in teaching choreography]. Obrazovanye y vospytanye - Education and upbringing, 2, 54-58 [in Ukrainian].

6. Kutsenko, S. V. (2015). Pedahohichna maisternist maibutnoho vchytelia khoreohrafii yak harant efektyvnosti formuvannia yoho tvorchoho potentsialu [Pedagogical skills of the future teacher of choreography as a guarantor of the effectiveness of the formation of his creative potential]. Aktualni pytannia mystetskoi osvity ta vykhovannia - Current issues of art education and upbringing, 1-2, 113-121 [in Ukrainian].

7. Martynenko, O. V. (2019). Vektory uspishnoi pidhotovky fakhivtsiv khoreohrafichnoho profiliu [Vectors of successful training of choreographers.]. Rozvytok tvorchoho potentsialu maibutnikh fakhivtsiv mystetskykh dystsyplin yak faktor yikh profesiinoi samorealizatsii : kolektyvna monohrafiia / Martynenko O. V. ta in.; za red. A. I. Omelchenko. Melitopol : Vydavnychyi budynok Melitopolskoi miskoi drukarni, 164-189 [in Ukrainian].

8. Nikolai, H. Yu. (2015). Predmet i teoretyko-metodolohichni osnovy khoreohrafichnopedahohichnoi komparatyvistyky [Subject and theoretical and methodological foundations of choreographic and pedagogical comparative studies]. Suchasni stratehii rozvytku khoreohrafichnoi osvity : materialy II Vseukr. nauk.-prakt. konf. (Uman, 16-17 trav. 2015 r.). Uman : FOP Zhovtyi O. O., 71-74 [in Ukrainian].

9. Parkhomenko, O. M. (2018). Do problemy baletmeisterskoi pidhotovky maibutnikh 241 uchyteliv khoreohrafii u systemi vyshchoi mystetskoi osvity[On the problem of choreography training of future 241 teachers of choreography in the system of higher art education]. Naukovi zapysky Nizhynskoho derzhavnoho universytetu imeni Mykoly Hoholia. Seriia: Psykholoho-pedahohichni nauky - Scientific notes of Nizhyn State University named after Nikolai Gogol. Series: Psychological and pedagogical sciences, 1, 33-38 [in Ukrainian].

10. Parkhomenko, O. M. (2019). Osnovni aspekty modeliuvannia khoreohrafichnoho tvoru v protsesi baletmeisterskoi diialnosti maibutnoho vchytelia khoreohrafii [The main aspects of modeling a choreographic work in the process of choreography of the future teacher of choreography]. Teoriia $\mathrm{i}$ metodyka mystetskoi osvity - Theory and methods of art education, 3, 118-124 [in Ukrainian]. 
11. Radchenko, O. L. Spetsyfika profesiinoi pidhotovky khoreohrafapedahoha, kerivnyka khoreohrafichnoho kolektyvu v mystetskykh navchalnykh zakladakh I-II rivnia akredytatsii [Specifics of professional training of choreographer, head of choreographic team in art schools of I-II level of accreditation]. Retrieved from http://www.kukim.org/articles/specifikaprofesiynoyi-pidgotovkihoreografa-pedagoga-kerivnika-horeografichnogokolektivu ((Accessed 30.09.2021) [in Ukrainian].

12. Rebrova ,O. Ye. (2017). Konstruiuvannia orhanizatsiino-metodychnoi systemy yak stratehiia fakhovoi pidhotovky maibutnikh uchyteliv muzyky i khoreohrafii [Construction of organizational and methodological system as a strategy of professional training of future teachers of music and choreography]. Naukovi zapysky Tsentralnoukrainskoho derzhavnoho pedahohichnoho universytetu imeni Volodymyra Vynnychenka. Seriia: Pedahohichni nauky - Scientific notes of the Central Ukrainian State Pedagogical University named after Volodymyr Vynnychenko. Series: Pedagogical sciences, 152, 41-46 [in Ukrainian].

13. Salo, L. V. (2019). Osoblyvosti pidhotovky khoreohrafiv u Kaliforniiskomu derzhavnomu universyteti [Features of training choreographers at California State University]. Mizhkulturna vzaiemodiia ta komunikatsiia: tradytsii, suchasnist, perspektyvy : materialy Vseukr. nauk.-prakt. konf. (Kaniv, 14-15 trav. 2019 r.). Kaniv, 80-82 [in Ukrainian].

14. Standart vyshchoi osvity Ukrainy (2020). Pershyi (bakalavrskyi) riven. Haluz znan: 02 Kultura i mystetstvo. Spetsialnist : 024. Khoreohrafiia. Kyiv : Ministerstvo osvity i nauky Ukrainy, 19 p. [in Ukrainian].

15. Taranenko, Yu. P., \& Koval, L. V. (2016). Kompetentnisnyi pidkhid u protsesi profesiinoi pidhotovky maibutnikh uchyteliv khoreohrafii [Competence approach in the process of professional training of future teachers of choreography]. Nauka i molod v KhKhI storichchi: zb. tez dopovidei II Mizhnar. molodizhnoi nauk.-prakt. Internetkonf. (Poltava, 1-2 hrud. 2016 r.): v 3 ch. Poltava: PUET, 2016. Ch. 2, 197-199 [in Ukrainian]. 